\title{
Interaction of 1,5-Substituted Pyrrolin-2-ones with Dichlorocarbene under Phase Transfer Catalysis Conditions
}

\author{
Alevtina Yu. Egorova*, Valentina A. Sedavkina and Zlata Yu. Timofeyeva \\ N.G. Tschernyschevsky Saratov State University, Astrakhanskaya 83, Saratov 410600, Russia \\ E-mail: TimofijiwaSU@info.sgu.ru
}

*Author to whom correspondence should be addressed

Received:14 Dec 1999; in revised form 27 Apr 2000 / Accepted: 20 Sep 2000 / Published: 31 Oct 2000

\begin{abstract}
Treatment of 5-alkyl(aryl)-3H-pyrrolin-2-ones with dichlorocarbene under phase transfer catalysis conditions at $20-30^{\circ} \mathrm{C}$ results in a cycloaddition of the carbene to the $\mathrm{C}=\mathrm{C}$ bond followed by skeletal rearrangement.
\end{abstract}

Keywords: 5-alkyl(aryl)-3H-pyrrolin-2-ones, 1-alkyl-6,6-dichloro-2-azabicyclo[3.1.0]-hexan3-ones, dichlorocarbene.

\section{Introduction}

The increasing interest in the chemistry of cyclopropanes results from the wide possibilities of their practical applications, in particular, as intermediates in organic syntheses and for obtaining biologically active compounds.

Reactions of carbenes with compounds containing multiple bonds under phase transfer catalysis (PTC) conditions of is an effective method for forming cyclopropane fragments. We were interested in studying the possibility of using five-membered nonaromatic $\mathrm{N}$-heterocycles containing $\mathrm{C}=\mathrm{C}$ and $\mathrm{C}=\mathrm{O}$ bond for the preparation of systems with cyclopropane or oxirane fragments.

\section{Results and Discussion}

In the present work 5-alkyl(aryl)-3H-pyrrolin-2-ones 1a-c were synthesized from 5-alkyl-3H-furan2-ones [1]. Dichlorocarbene was used as the carbene component. It was generated by the usual method, i.e., reaction of $\mathrm{NaOH}$ with chloroform in a two-phase system in the presence of 
benzyltriethylammonium bromide (BTEA) as the phase transfer catalyst.

The starting pyrrolin-2-ones contain several reaction centres that can react with diclorocarbene. These are the $\mathrm{C}=\mathrm{C}$ and $\mathrm{C}=\mathrm{O}$ double bonds, $\mathrm{C}-\mathrm{H}$ bonds and heteroatoms. It would be expected that the reaction product(s) would be determined by competing formation of the possible alternate dichlorocyclopropane structures, namely the products of nucleophilic addition of the trichloromethyl anion to the alkene or carbonyl carbon, the introduction of the dichlorocarbene into a $\mathrm{C}-\mathrm{H}$ bond and the formation of ylide structures due to carbene attack on the heteroatom free electron pair.

Under mild conditions $\left(20-30^{\circ} \mathrm{C}\right),[1+2]$-cycloaddition at the $\mathrm{C}=\mathrm{C}$ bond takes place to afford 1alkyl-6,6-dichloro-2-azabicyclo[3.1.0]-hexan-3-ones (3a-c).

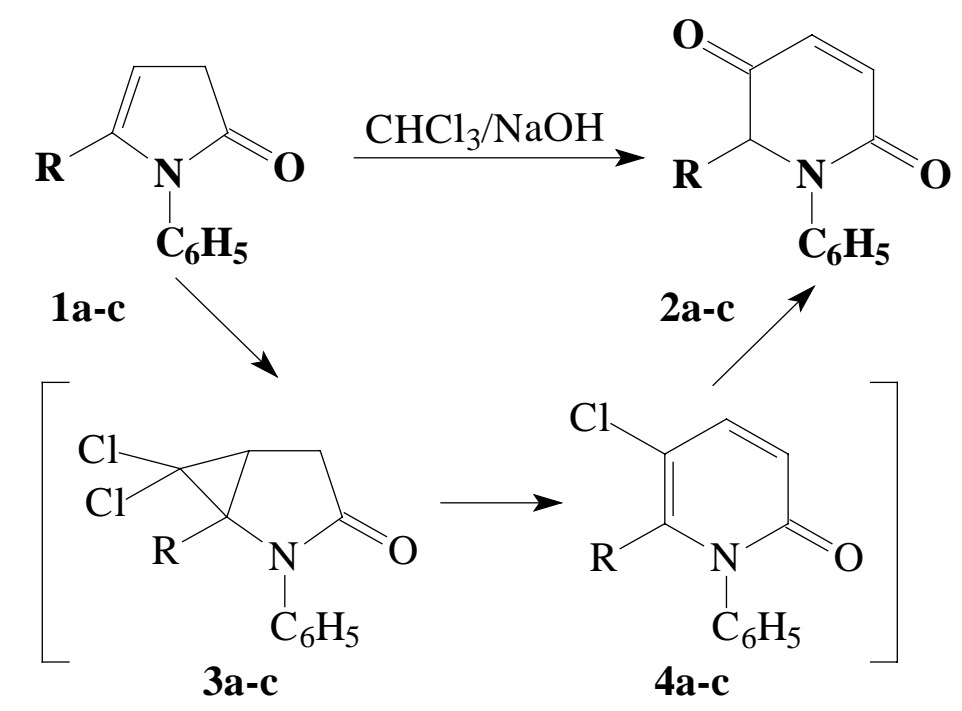

Scheme 1. Compounds 1-4: $\mathrm{R}=\mathrm{C}_{6} \mathrm{H}_{5}(\mathrm{a}), \mathrm{C}_{4} \mathrm{H}_{9}(\mathrm{~b}), \mathrm{C}_{5} \mathrm{H}_{11}(\mathrm{c})$

The formation of the products (4a-c) may occur through a skeletal rearrangement accompanied by expansion of the five-membered ring and dehydrochlorination. The net result is hydrolysis of compounds 4a-c and formation of 6-alkyl(aryl)-1-phenyl-5-oxohydropyridin-2-ones (2a-c). We failed to isolate the possible intermediates.

\section{Conclusions}

The reaction of 5-alkyl(aryl)-3H-pyrrolin-2-ones with dichlorocarbene at $20-30^{\circ} \mathrm{C}$ involves the $\mathrm{C}=\mathrm{C}$ bond and the aromatic fragment and the amide carbonyl of the substrates are not touched under the conditions investigated. When the reaction is carried out in a two-phase system, the side formation of the salts of the corresponding $\gamma$-keto-carboxylic acids was noted, due to the opening of fivemembered heterocycles under the action of alkali. 


\section{Experimental}

\section{General}

IR spectra were obtained on a UR-20 spectrometer. NMR spectra were recorded on a Varian FT$80 \mathrm{~A}$ instrument $(80 \mathrm{MHz})$ in $\mathrm{CDCl}_{3}$ using $\mathrm{SiMe}_{4}$ as the internal standard; the chemical shifts are given on the $\delta$ scale.

\section{6-Alkyl(aryl)-1-phenyl-5-oxohydropyridin-2-ones (2 a-c)}

A solution of $\mathrm{NaOH}(50 \%, 4 \mathrm{~mL})$ was added dropwise to a solution of 5-alkyl(aryl)-3H-pyrrolin-2ones $(1 \mathrm{a}-\mathrm{c})(0.08 \mathrm{~mol})$ and BTEA $(0.006 \mathrm{~mol})$ in chloroform $(25 \mathrm{~mL})$. The mixture was stirred at 20 $30^{\circ} \mathrm{C}$ for $48 \mathrm{~h}$. The organic layer was separated, and dried over $\mathrm{MgSO}_{4}$. The solvent was evaporated and the residue was recrystallized from ethanol to give compounds $\mathbf{2 a - c .}$

2a: m.p.150-152 ${ }^{\circ} \mathrm{C}, 82 \%$ yield. Anal. \% Calcd. for $\mathrm{C}_{17} \mathrm{H}_{13} \mathrm{O}_{2} \mathrm{~N}$ : C-77.63, H-4.98, N-5.33; Found: C78.10, H-5.05, N-5.60; ${ }^{1} \mathrm{H}-\mathrm{NMR}: 7.05$ (d, 1H), 7.50 (d, 1H, J $\left.\mathrm{J}_{34}=5.74 \mathrm{~Hz}\right), 2.10$ (c, 1H), 7.55-7.80 (m, 10H); ${ }^{13} \mathrm{C}-\mathrm{NMR}: 175.20,115.30,140.15,205.20,75.80,118.70,119.51,128.43,123.31,128.65$, $119.20,119.30,127.81,128.40,124.62,128.72,127.50$.

2b: m.p. $155-156^{\circ} \mathrm{C}, 80 \%$ yield. Anal. \% Calcd. for $\mathrm{C}_{15} \mathrm{H}_{17} \mathrm{O}_{2} \mathrm{~N}$ : C-74.14, H-7.05, N-5.76; Found: C-74.34, H-7.30, N-5.85; ${ }^{1} \mathrm{H}-\mathrm{NMR}: 7.10(\mathrm{~d}, 1 \mathrm{H}), 7.60\left(\mathrm{~d}, 1 \mathrm{H}, \mathrm{J}_{34}=5.75 \mathrm{~Hz}\right), 1.83(\mathrm{t}, 1 \mathrm{H}), 0.80-1.80$ (m, 9H), 7.63-7.75 (m, 5H); ${ }^{13} \mathrm{C}-\mathrm{NMR}: 175.40,115.35,140.12,204.85,75.90,32.15,20.43,16.05$, $12.10,118.75,120.12,129.52,122.31,129.32,119.55$.

2c: m.p. $158-159^{\circ} \mathrm{C}, 75 \%$ yield. Anal. \% Calcd for $\mathrm{C}_{16} \mathrm{H}_{19} \mathrm{O}_{2} \mathrm{~N}$ : C-74.77, H-7.45, N-5.45; Found: C74.92, H-7.65, N-5.70 ; ${ }^{1} \mathrm{H}-\mathrm{NMR}: 7.12(\mathrm{~d}, 1 \mathrm{H}), 7.64$ (d, 1H, J $\left.\mathrm{J}_{34}=5.67 \mathrm{~Hz}\right), 1.95(\mathrm{t}, 1 \mathrm{H}), 0.80-1.85$ (m, $11 \mathrm{H}), 7.70-7.78(\mathrm{~m}, 5 \mathrm{H}) ;{ }^{13} \mathrm{C}-\mathrm{NMR}: 175.10,115.60,140.25,205.62,75.51,32.44,30.12,23.25$, $20.45,11.15,118.72,119.65,128.50,122.25,128.65,119.85$.

\section{References}

1. Morozova, N.A.; Sedavkina,.A.; Egorova, A.Yu. Substituted 3H-furan-2ones in the hydroamination and amination reactions. Khim. Geterotsikl. Soedin. 1994, 349-352.

Sample Availability: Available from the authors.

(C) 2000 by MDPI (http://www.mdpi.org). Reproduction is permitted for noncommercial purposes. 